\title{
Pengaruh Konsentrasi Fenol terhadap Efektivitas Fotodegradasi Fenol menggunakan Komposit Titania-Carbon Nanotube-cocoPAS
}

\section{Effect of the Phenol Concentration on the Phenol Photodegradation Effectivity using Titania- Carbon Nanotube-cocoPAS Composite}

\author{
Desi Heltina*, Nadhia Gasani Putri, dan Panca Setia Utama
}

Jurusan Teknik Kimia, Fakultas Teknik, Universitas Riau, Kampus Bina Widya Jalan HR Soebrantas KM 12,5, Pekanbaru, 28293, Indonesia

\section{Artikel histori :}

Diterima 27 Agustus 2020

Diterima dalam revisi 25 Oktober 2020

Diterima 28 Oktober 2020

Online 31 Oktober 2020

\begin{abstract}
ABSTRAK: Senyawa aromatik dalam limbah cair industri seperti fenol dapat berkontribusi sebagai polutan yang tinggi toksisitas dan karsinogeniknya. Degradasi fenol dapat dilakukan dengan proses fotokatalisis yang dapat mengubah fenol menjadi senyawa yang tidak beracun dan ramah lingkungan. Kinerja fotokatalis titania $\left(\mathrm{TiO}_{2}\right)$ ditingkatkan dengan menggunakan carbon nanotube sebagai doping pada titania. Untuk mengurangi aglomerasi carbon nanotube, permukaan carbon nanotube dimodifikasi dengan surfaktan cocoPAS. Tujuan penelitian ini adalah membuat komposit titania-carbon nanotube-cocoPAS dan mengevaluasi pengaruh konsentrasi awal fenol (10, 20, $30 \mathrm{ppm})$ terhadap efektivitas fotodegradasi fenol menggunakan komposit titania-carbon nanotube-cocoPAS. Sintesis komposit titania-carbon nanotube-cocoPAS dilakukan dengan membentuk komposit antara $\mathrm{TiO}_{2}$ dan carbon nanotube yang telah dimodifikasi oleh surfaktan. Hasil komposit dikarakterisasi menggunakan SEM, FTIR, dan XRD. Fotodegradasi fenol dilakukan pada suhu degradasi $50^{\circ} \mathrm{C}$ selama 4 jam di bawah sinar UV. Sampel diambil dalam rentang waktu yang sama dan konsentrasi akhir fenol setiap sampel dianalisa menggunakan Spektrofotometer UV-Vis. Efektivitas degradasi selama 4 jam yang paling tinggi diperoleh pada konsentrasi awal 10 ppm yaitu sebesar $81 \%$.

Kata Kunci: fotokatalisis; degradasi; komposit; titania; carbon nanotube; fenol; konsentrasi
\end{abstract}

\begin{abstract}
Aromatic compounds in industrial wastewater such as phenols can contribute as pollutants which are highly toxic and carcinogenic. Phenol degradation can be carried out by a photocatalytic process which can convert phenol into non-toxic and enviromentally friendly compounds. The performance of titania $\left(\mathrm{TiO}_{2}\right)$ photocatalyst was enhanced by using carbon nanotube as a doping agent for titania. To reduce carbon nanotube agglomeration, the surface of carbon nanotube was modified with cocoPAS surfactant. The purpose of this study was to synthesize titania-carbon nanotube-cocoPAS composite and evaluated the effect of initial phenol concentration $(10,20,30 \mathrm{ppm})$ on the phenol photodegradation effectivity using titania-carbon nanotube-cocoPAS composite. Titania-carbon nanotube-cocoPAS composite synthesis was carried out by forming a composite between $\mathrm{TiO}_{2}$ and carbon nanotube that had been modified by surfactant. Composite were characterized by SEM, FTIR, and XRD. Phenol photodegradation was carried out at a degradation temperature of $50^{\circ} \mathrm{C}$ for 4 hours under UV light. Samples were drawn at regular intervals and residual concentration of phenol in each sample was analysed using UV-Visible spechtrophotometer. The highest degradation effectivity in 4 hours was $81 \%$ at initial phenol concentration of $10 \mathrm{ppm}$.
\end{abstract}

Keywords: photocatalysis; degradation; composite; titania; carbon nanotube; phenol; concentration

\section{Pendahuluan}

Senyawa aromatik terdapat dalam limbah cair beberapa industri seperti industri pestisida, gasifikasi batu bara, tekstil dan petrokimia, salah satunya adalah fenol. Senyawa fenol
$\left(\mathrm{C}_{6} \mathrm{H}_{5} \mathrm{OH}\right)$ merupakan senyawa organik yang mempunyai toksisitas yang tinggi dan berpotensi menjadi karsinogenik dikarenakan sifat bioakumulasinya (Safni dkk., 2019). Ekstraksi elektrokimia, adsorpsi karbon aktif, proses oksidasi dan desinfeksi, filtrasi, dan proses aerob dan anaerob merupakan beberapa proses yang dapat dilakukan

*Corresponding Author: +62 8127698263

Email: desi.heltina@lecturer.unri.ac.id 
untuk mendegradasi atau menghilangkan fenol. Namun, proses-proses tersebut membutuhkan waktu yang lama, regenerasi bahan secara berkala dan bahkan menghasilkan produk samping berupa senyawa polutan lain (Dang dkk., 2016).

Fotokatalisis merupakan salah satu jenis proses Advanced Oxidation Process (AOPs) yang dapat mendegradasi fenol menjadi senyawa yang tidak beracun dan ramah lingkungan, yaitu $\mathrm{CO}_{2}$ dan $\mathrm{H}_{2} \mathrm{O}$ (Ani dkk., 2018). Proses ini dapat menghasilkan senyawa radikal yang sangat reaktif seperti radikal hidroksil $(\mathrm{OH} \bullet)$ yang dihasilkan dari reaksi oksidasi atau reduksi dari masing-masing elektron dan hole. Senyawa radikal hidroksil $(\mathrm{OH} \bullet)$ inilah yang akan menguraikan senyawa fenol. Elektron dan hole dihasilkan dari fotokatalis yang tereksitasi oleh foton dari sumber cahaya. Energi foton harus mempunyai energi yang sama atau lebih besar dari energi band gap fotokatalis (Rahmani dkk., 2019).

Titania/titanium dioksida $\left(\mathrm{TiO}_{2}\right)$ merupakan fotokatalis semikonduktor yang baik untuk proses fotokatalisis berdasarkan sifat stabilitas mekanik dan termalnya yang tinggi, tidak beracun, sifat optiknya yang baik, mudah diperoleh dan ketersediaan yang tinggi, stabilitas kimia dalam jangka waktu yang panjang dan kemampuan oksidasi yang kuat (Ai dkk., 2019). Namun, $\mathrm{TiO}_{2}$ mempunyai laju rekombinasi yang tinggi antara elektron dan hole, yang dapat menyebabkan berkurangnya radikal hidroksil $(\mathrm{OH} \cdot)$ yang terbentuk (Shahbazi dkk., 2018). Salah satu perlakuan yang dapat dilakukan untuk mengurangi rekombinasi antara elektron dan hole dan meningkatkan aktivitas fotokatalis $\mathrm{TiO}_{2}$ adalah dengan membentuk komposit antara $\mathrm{TiO}_{2}$ dengan material lain (Shawabkeh dkk., 2010).

Carbon nanotube (CNT) merupakan material yang berpotensi untuk meningkatkan aktivitas fotokatalisis dengan membentuk komposit $\mathrm{TiO}_{2}-\mathrm{CNT}$. Carbon nanotube mempunyai kapasitas penyimpanan elektron yang besar sehingga dapat menjadi electron-acceptor agar menurunkan laju rekombinasi $\mathrm{TiO}_{2}$ (Alwash dkk., 2018). Ikatan van der Waals carbon nanotube yang kuat menyebabkan carbon nanotube cenderung beraglomerasi sehingga sulit terdispersi saat digabungkan dengan material lain. Maka dari itu, sebelum dikompositkan dengan $\mathrm{TiO}_{2}$, dilakukan modifikasi permukaan carbon nanotube dengan surfaktan sebagai agen pendispersi agar terbentuk ikatan yang kuat antara $\mathrm{TiO}_{2}$ dan carbon nanotube (Gangu dkk., 2019).

Li dan Qiu (2019) menggunakan surfaktan sodium dodecyl sulfate (SDS) untuk mendispersi carbon nanotube. Interaksi antara carbon nanotube dan SDS merupakan interaksi non-kovalen yang dapat berupa interaksi $\pi-\pi$, gaya van der Waals dan gaya elektrostatis (Lamprecht dkk., 2011). Namun, SDS merupakan salah satu surfaktan anionik sintetis. Pada jumlah tertentu, surfaktan sintetis berpotensi menjadi pencemar di lingkungan, maka dari itu surfaktan yang berasal dari bahan alami yang bersifat biodegradable dapat menjadi pengganti surfaktan sintetis. Surfaktan cocoPAS (coconut-oil based primary alkyl sulfate) merupakan surfaktan anionik yang berasal dari minyak kelapa (Richards dkk., 2009). Surfaktan cocoPAS merupakan turunan SDS sehingga dapat menjadi pendispersi terbarukan pengganti SDS pada carbon nanotube. Berdasarkan pendekatan tersebut, maka dilakukan pembuatan komposit titania-carbon nanotube-cocoPAS untuk mendegradasi fenol dimana carbon nanotube dimodifikasi terlebih dahulu menggunakan surfaktan yang bersifat biodegradable.

Degradasi fenol menggunakan proses fotokatalisis dapat disebut sebagai fotodegradasi fenol. Konsentrasi awal fenol yang digunakan mempengaruhi hasil konsentrasi akhir fenol dikarenakan laju degradasi pada konsentrasi awal yang sama berbeda dengan laju degradasi pada konsentrasi awal yang berbeda (Chowdhury dkk., 2017). Pada penelitian ini, dilakukan fotodegradasi fenol dengan variasi konsentrasi awal fenol yaitu 10 ppm, 20 ppm, dan 30 ppm. Tujuan dari penelitian ini adalah untuk mengevaluasi pengaruh konsentrasi awal fenol terhadap efektivitas fotodegradasi fenol menggunakan komposit titania-carbon nanotubecocoPAS.

\section{Metode Penelitian}

\subsection{Alat dan Bahan}

Bahan yang digunakan pada penelitian ini diantaranya yaitu titania $\left(\mathrm{TiO}_{2} \mathrm{P} 25\right.$ dibeli dari Evonic Industries), carbon nanotube (tipe MWCNT/multi-walled carbon nanotube yang dibeli dari Dong Yang (HK) Int'l Group Limited dengan diameter 10-30 $\mathrm{nm}$, panjang 5-15 $\mu \mathrm{m}$, dan kemurnian 99\%), surfaktan cocoPAS (coconut-oil based primary alkyl sulfate) yang diperoleh dari PT. KAO Indonesia, $\mathrm{HNO}_{3} 1 \mathrm{M}$, akuades dan fenol (pure analysis).

Alat yang digunakan pada penelitian ini yaitu gelas kimia $250 \mathrm{ml}$ dan $1000 \mathrm{ml}$, sonikator tipe bath $550 \mathrm{~W}, 37 \mathrm{kHz}$ (Elmasonic S $60 \mathrm{H}$, Jerman), pompa vakum (KNF Neuberger Laboport, USA), erlenmeyer vakum $250 \mathrm{ml}$ (Schott Duran, Jerman), sintered glass crucible porosity no.4 (Schott Duran, Jerman), vacuum oven (Gallenkamp, China), magnetic stirrer (Thermo Scientific Cimarec ${ }^{+}$, Jerman), indikator universal, pipet ukur $5 \mathrm{ml}$ dan $10 \mathrm{ml}$, rangkaian alat kalsinasi (fixed bed reactor), centrifuge (802B Centrifuge, China), 25 buah botol sampel $5 \mathrm{ml}$ serta 6 buah lampu UV Blacklight Blue (BLB) tipe A merk Sankyo Denki $10 \mathrm{~W}$. Gambar 1 menunjukkan rangkaian alat fotoreaktor untuk proses fotodegradasi fenol menggunakan komposit titania-carbon nanotube-cocoPAS.

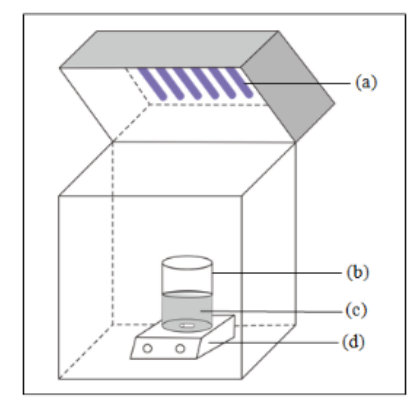

Gambar 1. Rangkaian Proses Fotodegradasi Fenol (a) Lampu UV (b) Gelas Kimia (c) Larutan Fenol + Komposit/Sampel (d) Magnetic Stirrer 


\subsection{Prosedur Penelitian}

Penelitian ini dimulai dengan memodifikasi permukaan carbon nanotube dengan surfaktan (cocoPAS). Satu gram carbon nanotube dan 0,5 gram surfaktan cocoPAS ditambahkan dalam $100 \mathrm{ml}$ akuades. Selanjutnya, campuran tersebut disonikasi selama 1 jam pada $550 \mathrm{~W}(37 \mathrm{kHz})$ dan disaring menggunakan rangkaian alat vakum. Padatan yang dihasilkan dari penyaringan tersebut kemudian dikeringkan menggunakan oven selama 1-2 jam pada suhu $110^{\circ} \mathrm{C}$. Padatan yang telah dikeringkan merupakan padatan carbon nanotube-cocoPAS

Setelah diperoleh padatan carbon nanotube-cocoPAS, dilakukan pembuatan komposit. Carbon nanotube-cocoPAS sebanyak 0,015 gram dilarutkan dalam $100 \mathrm{ml}$ akuades dan kemudian disonikasi selama 30 menit. Setelah itu, ditambahkan 1 gram titania dan disonikasi kembali selama 30 menit. Selanjutnya, untuk mengatur $\mathrm{pH}$ campuran, diteteskan beberapa tetes $\mathrm{HNO}_{3} 1 \mathrm{M}$ hingga pHnya menjadi 3. Menurut Park dkk (2009), pH 3 pada campuran dapat memperkuat ikatan komposit. Kemudian, campuran diaduk menggunakan magnetic stirrer selama 3 jam dengan kecepatan pengadukan $300 \mathrm{rpm}$. Lalu, campuran dikeringkan di oven pada suhu $110^{\circ} \mathrm{C}$ untuk menguapkan akuades dengan waktu kurang lebih 1-2 jam. Kemudian, padatan yang diperoleh dihaluskan dan dikalsinasi menggunakan rangkaian alat kalsinasi pada suhu $400^{\circ} \mathrm{C}$ selama 2 jam.

Kinerja komposit titania-carbon nanotube-cocoPAS dalam mendegradasi fenol dilakukan dalam fotoreaktor menggunakan lampu UV. Larutan fenol dibuat dalam gelas kimia dengan konsentrasi awal fenol (Cao) sesuai variasi 10 ppm, 20 ppm, dan 30 ppm dalam $300 \mathrm{ml}$. Kemudian, komposit dimasukkan ke dalam gelas kimia yang berisi larutan fenol tersebut sebanyak 0,3 gram. Suhu degradasi yang digunakan yaitu $50^{\circ} \mathrm{C}$. Sampel larutan diambil sebanyak $2 \mathrm{ml}$ setiap 30 menit selama 4 jam. Kemudian endapan di dalam sampel dipisahkan menggunakan centrifuge selama 10 menit.

\subsection{Metode Analisis}

Beberapa pengujian karakteristik komposit titania-carbon nanotube -cocoPAS yang dilakukan adalah analisis Scanning Electron Microscope (SEM) untuk mengetahui morfologi komposit, analisis spektrofotometri FTIR (Fourier-transform Infrared Spectroscopy) untuk karakterisasi gugus fungsi pada komposit, analisis dengan menggunakan difraktometer sinar-X (XRD) untuk mengetahui struktur kristal. Ukuran kristal dihitung menggunakan persamaan Scherrer, yaitu:

$$
\mathrm{D}=\frac{\mathrm{k} \lambda}{\beta \cos \theta}
$$

dimana D adalah ukuran kristal; $\mathrm{k}$ adalah konstanta $(0,89) ; \lambda$ adalah panjang gelombang X-ray $(0,154056 \mathrm{~nm})$; $\beta$ adalah full width at half maximum intensity (FWHM) dan $\theta$ adalah sudut setengah difraksi.
Fraksi kristal anatase dan rutile dihitung menggunakan persamaan metode Spurr dan Myers (S\&M), yaitu:

$$
\mathrm{X}_{\mathrm{R}}=\left(1+0,8 \frac{\mathrm{I}_{\mathrm{A}}}{\mathrm{I}_{\mathrm{R}}}\right)^{-1}
$$

dimana $X_{R}$ adalah fraksi rutile, $I_{A}$ adalah intensitas anatase dan $I_{R}$ adalah intensitas rutile. $I_{A}$ dan $I_{R}$ dapat diperoleh dari data hasil karakterisasi XRD. Fraksi anatase $\left(\mathrm{X}_{\mathrm{A}}\right)$ diperoleh dengan $\mathrm{X}_{\mathrm{A}}=1-\mathrm{X}_{\mathrm{R}}$. Data-data tersebut dapat diperoleh dari hasil karakterisasi XRD.

Sampel larutan fenol hasil degradasi dianalisis dengan metode analisis SNI 06-6989.21-2004 menggunakan spektrofotometer UV-Vis pada panjang gelombang $500 \mathrm{~nm}$. Larutan standar yang digunakan untuk kalibrasi adalah larutan fenol pada konsentrasi 0 sampai dengan $50 \mathrm{ppm}$. Hasil kalibrasi berupa persamaan $\mathrm{y}=\mathrm{ax}+\mathrm{b}$ yang digunakan untuk mengetahui konsentrasi akhir fenol $(\mathrm{Ca})$. Efektivitas degradasi fenol dihitung menggunakan persamaan (3) sebagai berikut:

$$
\frac{\mathrm{Cao}-\mathrm{Ca}}{\mathrm{Cao}} \times 100 \%
$$

dimana Cao adalah konsentrasi awal fenol dan $\mathrm{Ca}$ adalah konsentrasi akhir fenol.

\section{Hasil dan Pembahasan}

\subsection{Karakterisasi Komposit Titania-Carbon Nanotube-cocoPAS}

Morfologi komposit titania-carbon nanotube-cocoPAS diperoleh dari hasil karakterisasi SEM yang dapat dilihat pada Gambar 2. Morfologi titania partikel berupa gumpalan atau bongkahan-bongkahan partikel, sedangkan morfologi carbon nanotube berupa tubular/silinder panjang serabut yang bercabang (Heltina dkk., 2014).

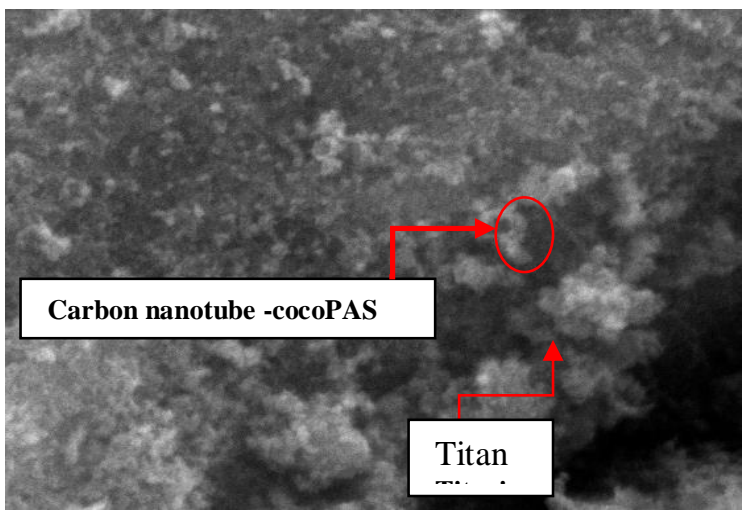

Gambar 2. Morfologi Komposit Titania-Carbon Nanotube-cocoPAS

Pada Gambar 2, dapat dilihat bahwa terdapat tubular/silinder panjang yang merupakan carbon nanotubecocoPAS di antara persebaran gumpalan partikel yang merupakan titania. Hal tersebut menunjukkan bahwa telah terbentuk ikatan antara titania dan carbon nanotubecocoPAS. Morfologi komposit didominasi oleh titania 
disebabkan jumlah massa titania yang lebih dominan dibandingkan dengan carbon nanotube-cocoPAS.

Selain dari morfologi, terbentuknya komposit titaniacarbon nanotube-cocoPAS juga dapat dilihat dari gugus fungsi dan ikatan yang terdapat dalam komposit berdasarkan karakterisasi FTIR pada panjang gelombang 450-4500 $\mathrm{cm}^{-1}$. Pada Gambar 3, dapat dilihat hasil FTIR dari komposit titania-carbon nanotube-cocoPAS. Keberadaan carbon nanotube pada komposit titania-carbon nanotube-cocoPAS ditandai dengan adanya puncak pada $2889,53 \mathrm{~cm}^{-1}$ yang menunjukkan ikatan $\mathrm{C}-\mathrm{H}, 1573,98 \mathrm{~cm}^{-1}$ yang menunjukkan ikatan $\mathrm{C}=\mathrm{C}$, dan $1714,79 \mathrm{~cm}^{-1}$ yang menunjukkan ikatan $\mathrm{C}=\mathrm{O}$ (Zueva dkk., 2016). Bilangan gelombang 602,78 sampai $678,01 \mathrm{~cm}^{-1}$ menunjukkan gugus fungsi Ti-O yang berasal dari ikatan Ti-O-Ti (Neto dkk., 2017). Bilangan gelombang $1651,14 \mathrm{~cm}^{-1}, 2360,97 \mathrm{~cm}^{-1}$, dan $3084,31 \mathrm{~cm}^{-1}$ menunjukkan ikatan -OH (Shaban dkk., 2018). Menurut Zabihi dkk (2017), ikatan Ti-O-C dapat muncul pada bilangan gelombang $3100 \mathrm{~cm}^{-1}$. Pada komposit titania-carbon nanotube-cocoPAS diperoleh puncak pada $3129,64 \mathrm{~cm}^{-1}$ yang menunjukkan adanya ikatan Ti-O-C pada komposit.

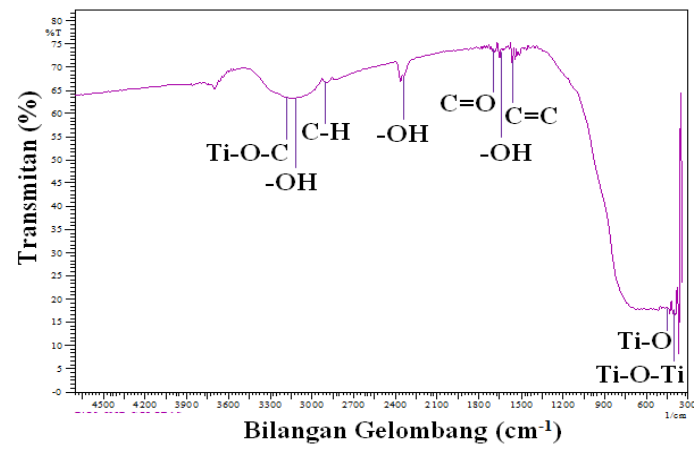

Gambar 3. Hasil FTIR Komposit Titania-Carbon Nanotube-cocoPAS

Fasa kristalin dari titania juga mempengaruhi proses fotokatalisis untuk mendegradasi fenol. Campuran antara fase anatase dan fase rutile menunjukkan aktivitas fotokatalitik yang baik (Luttrell dkk., 2014). Ukuran kristal juga dapat mempengaruhi proses fotokatalisis dikarenakan semakin kecil ukuran kristal maka luas permukaan dan kapasitas adsorpsi pada fotokatalis akan semakin besar. Semakin kecil ukuran kristal anatase maka akan semakin besar kapasitas adsorpsi dari anatase dibandingkan rutile. Ukuran kristal yang semakin kecil akan meningkatkan jumlah situs aktif titania (Zhang dkk., 2014).

Berdasarkan persamaan (1) dan (2), fraksi kristal dan ukuran kristal yang diperoleh pada komposit titania-carbon nanotube-cocoPAS dapat dilihat pada Tabel 1. Fraksi anatase yang lebih besar akan meningkatkan aktivitas fotokatalisis dikarenakan anatase mempunyai luas permukaan adsorpsi yang lebih besar untuk gugus hidroksil dan laju rekombinasi yang lebih rendah dibandingkan dengan rutile (Zhang dkk., 2014).
Tabel 1. Ukuran dan Fraksi Kristal pada Komposit Titania-Carbon Nanotube-cocoPAS

\begin{tabular}{ccc}
\hline Keterangan & $\begin{array}{c}\text { Fraksi } \\
\text { Kristal }(\%)\end{array}$ & $\begin{array}{c}\text { Ukuran } \\
\text { Kristal (nm) }\end{array}$ \\
\hline Anatase & 85,19 & 18,82 \\
Rutile & 14,81 & 26,15 \\
\hline
\end{tabular}

\subsection{Pengaruh Konsentrasi Awal Fenol terhadap Efektivitas Fotodegradasi Fenol}

Variasi konsentrasi awal fenol (Cao) yang digunakan adalah 10 ppm, 20 ppm, dan 30 ppm dalam suhu degradasi yang tetap yaitu $50^{\circ} \mathrm{C}$. Konsentrasi akhir fenol (Ca) diperoleh dari perhitungan menggunakan absorbansi dari hasil analisa spektrofotometer UV-Vis. Pada Gambar 4 dapat dilihat pengaruh konsentrasi terhadap kinerja fotokatalis yang berupa komposit titania-carbon nanotube. Pada Gambar 4 tersebut ditunjukkan bahwa semakin rendah konsentrasi fenol, maka akan semakin cepat penurunan konsentrasinya. Perbandingan antara konsentrasi akhir ( $\mathrm{Ca}$ ) dan konsentrasi awal (Cao) pada Gambar 4 tersebut menunjukkan perubahan konsentrasi per 30 menit. Perbandingan efektivitas degradasi terhadap konsentrasi fenol dapat dilihat pada Gambar 5 yang menunjukkan semakin tinggi konsentrasi awal fenol maka akan semakin rendah persen degradasi yang dihasilkan.

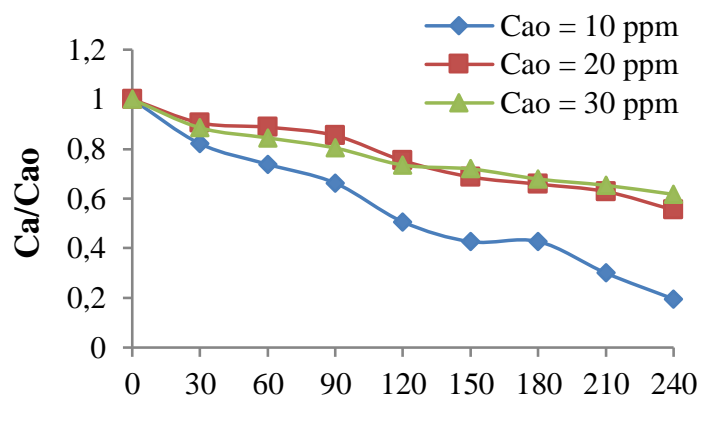

Waktu (menit)

Gambar 4. Pengaruh Konsentrasi Fenol terhadap Kinerja Fotokatalis

Pada permukaan titania terdapat situs aktif yang mempunyai ikatan - OH yang dapat bereaksi membentuk radikal hidroksil (Deiana dkk., 2010). Semakin banyak jumlah awal fenol, maka akan semakin berkurang situs aktif yang tersedia pada permukaan titania. Selama intensitas cahayanya tetap, dan waktu degradasinya tetap, maka jumlah radikal hidroksil yang terbentuk juga tetap (Laoufi dkk., 2008). Apabila semakin sedikit situs aktif titania, maka radikal hidroksil yang terbentuk akan berkurang dan menurunkan efektivitas degradasi fenol. 


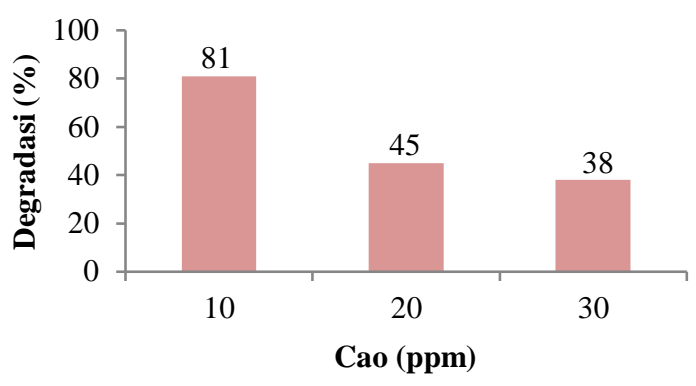

Gambar 5. Perbandingan Efektivitas Degradasi terhadap Konsentrasi Fenol

Reaksi pada proses fotodegradasi fenol antara fenol (senyawa organik) dengan radikal hidroksil $(\mathrm{OH} \bullet)$ yang dihasilkan dari proses fotokatalisis dapat dilihat pada persamaan (4). Berdasarkan persamaan (4) tersebut dapat diketahui bahwa semakin banyak radikal hidroksil yang terbentuk, maka akan semakin banyak fenol yang terdegradasi (Dong dkk., 2015).

$$
\mathrm{R}-\mathrm{H}+\mathrm{OH} \cdot \rightarrow \mathrm{R} \cdot+\mathrm{H}_{2} \mathrm{O}
$$

Permukaan titania mempunyai gugus hidroksil yang dapat bertindak sebagai donor elektron dalam pembentukan $\mathrm{H}^{+}$ dan bereaksi dengan $\mathrm{h}^{+}$sehingga dapat meningkatkan jumlah radikal hidroksil yang dapat mendegradasi senyawa organik (Zhang dkk., 2016). Maka dari itu, titania merupakan agen fotokatalis yang dapat meningkatkan degradasi senyawa organik. Pada Tabel 2 terdapat perbandingan efektivitas degradasi fenol selama 4 jam antara carbon nanotube murni (tipe MWCNT) dan komposit titania-carbon nanotube-cocoPAS, Berdasarkan Tabel 2 tersebut, diketahui bahwa terjadi peningkatan persen degradasi fenol pada material yang terdapat titania.

Tabel 2. Perbandingan Efektivitas Degradasi Fenol tanpa Titania pada Suhu Degradasi $30^{\circ} \mathrm{C}$

\begin{tabular}{cc}
\hline Keterangan & Degradasi \\
\hline MWCNT & $29 \%$ \\
Titania-Carbon Nanotube-cocoPAS & $72 \%$ \\
\hline
\end{tabular}

Ho dkk (2020) melakukan proses fotodegradasi fenol menggunakan metode sol/gel dengan mengkompositkan titania dengan $\mathrm{SiO}_{2}$. Pada Tabel 3 ditunjukkan bahwa selama 4 jam pada konsentrasi awal fenol 10 ppm diperoleh efektivitas degradasi komposit titania-carbon nanotubecocoPAS lebih tinggi dibandingkan $\mathrm{TiO}_{2} / \mathrm{SiO}_{2}$. Maka dari itu, terjadi peningkatan efektivitas degradasi dengan mengkompositkan $\mathrm{TiO}_{2}$ dan carbon nanotube yang dimodifikasi dengan surfaktan cocoPAS.
Tabel 3. Perbandingan Efektivitas Degradasi Fenol dengan Metode Lain

\begin{tabular}{ccc}
\hline Keterangan & $\begin{array}{c}\mathrm{TiO}_{2} / \mathrm{SiO}_{2} \\
\text { (Ho dkk., 2020) }\end{array}$ & $\begin{array}{c}\text { Titania- } \\
\text { Carbon } \\
\text { Nanotube- } \\
\text { cocoPAS }\end{array}$ \\
\hline $\begin{array}{c}\text { Efektivitas } \\
\text { Degradasi }\end{array}$ & $53,5 \%$ & $81 \%$ \\
\hline
\end{tabular}

\section{Kesimpulan}

Komposit titania-carbon nanotube-cocoPAS telah disintesis dengan memodifikasi permukaan carbon nanotube terlebih dahulu dengan surfaktan. Efektivitas komposit titaniacarbon nanotube-cocoPAS yang paling tinggi dalam mendegradasi fenol selama 4 jam adalah pada konsentrasi 10 ppm yaitu $81 \%$.

\section{Ucapan Terimakasih}

Penulis mengucapkan terima kasih kepada DRPM Universitas Riau dan Direktorat Jenderal Pendidikan Tinggi (Ditjen Dikti) Kementerian Pendidikan Nasional Republik Indonesia atas dukungan dana penelitian (Hibah) Penelitian Dasar, no. 395 / UN.19.5.1.3 / PT.01.03 / 2020.

\section{Daftar Pustaka}

Ai, M., Wenli, Q., Tian, X., Ying, Y., Xuegang, C. \& Pingping, Z., 2019, Photocatalytic degradation of 2,4Dichlorophenol by $\mathrm{TiO}_{2}$ intercalated talc nanocomposite, International Journal of Photoenergy, Vol. 2019, Maret: $1-11$.

Alwash, A., Hadeel, A., Zainab, H. \& Emad, Y., 2018, Potential of carbon nanotubes in enhance of photocatalyst activity, Archives of Nanomedicine: Open Access Journal, Vol.1 No.3, Juni: 65-70.

Ani, I.J., Akpan, U.G., Olutoye,M.A. \& Hameed, B.H., 2018, Photocatalytic degradation of pollutants in petroleum refinery wastewater by $\mathrm{TiO}_{2}$ - and $\mathrm{ZnO}$ - based photocatalysts: Recent development, Journal of Cleaner Production, Vol.205, Agustus: 930-954.

Chowdhury, P., Sharmistha, N. \& Ajay, K.R., 2017, Degradation of phenolic compounds through UV and visible-light-driven photocatalysis: Technical and economic aspects. Di dalam: Hernandez, M.S. (ed). Phenolic Compounds Natural Sources, Importance and Applications. hlm 395-417. InTech, Open Science, doi: $10.5772 / 66134$.

Dang, T.T.T., Le,S.T.T., Channel, D.,Khanitchaidecha, W. \& Nakaruk, A., 2016, Photodegradation mechanisms of phenol in the photocatalytic process, Research on Chemical Intermediates, Vol.42 No.6, Desember: 59615974.

Deiana, C., Ettore, F., Salvatore, C. \& Gianmaria, M., 2010, Surface structure of $\mathrm{TiO}_{2}$ P25 nanoparticles: infrared study of hydroxy groups on coordinative defect sites, Journal of Physical Chemistry C, Vol.114 No.49, November: 21531-21538. 
Dong, H., Guangming, Z., Lin, T., Changzheng, F., Chang, Z., Xiaohiao, H., \& Yan, H, 2015, An overview on limitations of $\mathrm{TiO}_{2}$-based particles for photocatalytic degradation of organic pollutants and the corresponding countermeasures, Water Research, Vol.79, Mei: 128146.

Gangu, K.K., Suresh, M. \& Sreekantha, B.J., 2019, A review on novel composites of MWCNTs mediated semiconducting materials as photocatalysts in water treatment, Science of the Total Environment, Vol.646, Juli: 1398-1412.

Heltina, D., Karina, O.V. \& Slamet., 2014, Efektivitas kinerja komposit carbon nanotube-titania untuk eliminasi fenol, Simposium Nasional RAPI XII.K-42 K-49, Universitas Muhammadiyah Surakarta, ISSN: 1412-9612.

Ho, T.N.S, Nguyen, T.T., Pham, T.H.T., Ngo, M.T., \& Le, M.V, 2020, Photocatalytic degradation of phenol in aqueous solutions using $\mathrm{TiO}_{2} / \mathrm{SiO}_{2}$ composite, Chemical Engineering Transactions, Vol.78, Februari: 427-432.

Lamprecht, C., J. Torin, H., Marina, V.I \& Marianna, F., 2011, Non-covalent functionalization of carbon nanotubes with surfactants for pharmaceutical applications- A critical mini-review, Drug Delivery Letters, Vol.1 No.1, Juli: 45-57.

Laoufi, N.A., Tassalit,D. \& Bentahar, F., 2008, The degradation of phenol in water solution by $\mathrm{TiO}_{2}$ photocatalysis in a helical reactor, Global NEST Journal, Vol.10 No.3, Januari: 404-418.

Li, H., \& Qiu, Y., 2019, Dispersion, sedimentation and aggregation of multi-walled carbon nanotubes as affected by single and binary mixed surfactants, Royal Society Open Science, Vol.6 No.7, Juli: 1-9.

Luttrell, T., Sandamali, H., Junguang, T., Alan, K., Eli, S. \& Matthias, B., 2014, Why is anatase a better photocatalyst than rutile? -Model studies on epitaxial $\mathrm{TiO}_{2}$ films, Scientific Reports, Vol.4 No.4043, Februari: 1-9, doi: 10.1038/srep04043.

Neto, J.O.M., Carlos, R.B., Carlos, H.F.S., Rene, C.S. \& Pablo, A.R., 2017, Synthesis, characterization and enhanced photocatalytic activity of iron oxide/carbon nanotube/Ag-doped $\mathrm{TiO}_{2}$ nanocomposites, Journal Brazil Chemical Society, Vol.28 No.12, Mei: 2301-2312.

Park, K., En, M.J., Hal, B.G., Sang, E.S. \& Chang, K.H., 2009, Effects of $\mathrm{HNO}_{3}$ treatment of $\mathrm{TiO}_{2}$ nanoparticles on the photovoltaic properties of dye-sensitized solar cells, Material Letters, Vol.63 No.26, Juli: 2208-2211.

Rahmani, A., Hadi, R. \& Somayeh, B., 2019, Photocatalytic degradation of phenolic compound (phenol, resorcinol and cresol) by titanium dioxide photocatalyst on ordered mesoporous carbon (CMK-3) support under UV irradiation, Desalination and Water Treatment, Vol.144, Juni: 224-232.

Richards, C., Mansur, S.M. \& Gordon, J.T.T., 2009, Formulating liquid detergents with naturally derived surfactants-phase behaviour, crystallisation and rheostability of primary alkyl sulfates based on coconut oil, Colloids and Surfaces A: Physicochemical and Engineering Aspects, Vol.338 No.1-3, April: 119-128.
Safni, Mechy R.W., Khoiriah, \& Yulizar, Y., 2019, Photodegradation of phenol using N-doped $\mathrm{TiO}_{2}$ catalyst, Molekul, Vol.14 No.1, Mei: 6-10.

Shaban, M., Abdallah, M.A. \& Mostafa, R.A., 2018, TiO 2 nanoribbons/carbon nanotubes composite with enhanced photocatalytic activity; fabrication, characterization, and application, Scientific Reports, Vol.8 No.1, Januari: 1-17.

Shahbazi, H., Alireza, S. \& Saeed, S., 2018, The effect of carbon nanotubes functionalization on the band-gap energy of $\mathrm{TiO}_{2}$-CNT nanocomposites, AIP Conference Proceedings, hlm. 0200401-0200404.

Shawabkeh, R.A., Omar, A.K. \& Gasan, I.B., 2010, Photocatalytic degrdation of phenol using $\mathrm{Fe}-\mathrm{TiO}_{2}$ by different illumination sources, International Journal of Chemistry, Vol.2 No.2, July: 10-18.

Zabihi, F., Mohamed, R.A.Y. \& Morteza, E., 2017, Photocatalytic graphene- $\mathrm{TiO}_{2}$ thin films fabricated by low-temperature ultrasonic vibration-assisted spin and spray coating in a sol-gel process, Catalysts, Vol.7 No.5, Mei: 1-16.

Zhang, J., Peng, Z., Jianjun, L. \& Jiaguo, Y., 2014, New understanding of the difference of photocataytic activity among anatase, rutile and brookite $\mathrm{TiO}_{2}$, Physical Chemistry Chemical Physics, Vol.6 No.38, Agustus: 20382-20386.

Zhang, Q., Nan, B., Xinqiang, W., Xinde, H., Xinhan, M., Mohamed, C., \& Dongling, M., 2016, Advanced fabrication of chemical bonded graphene $/ \mathrm{TiO}_{2}$ continuous fibers with enhanced broadband photocatalytic properties and involved mechanisms exploration, Scientific Reports, Vol.6 No.38066, Desember: 1-15. doi: 10.1038/srep38066.

Zueva, O.S., Makshakova, O.N., Idiyatullin, B.Z., Faizullin,D.A., Benevolenskaya, N.N., Borovskaya, A.O. \& Yu, F.Z., 2016, Structure and properties of aqueous dispersions of sodium dodecyl sulfate with carbon nanotubes, Russian Chemical Bulletin, International Edition, Vol.65 No.5, Mei: 1208-1215. 